у сучасної молоді, як наслідок швидкісного переходу від імперської провінції до незалежності, $\epsilon$ додатковим дезадаптуючим чинником на тлі загальної суспільної невизначеності. 3 ним пов'язані намагання молоді ідентифікувати себе 3 деструктивними культами, що виявляються в етнічних химерах на межі суперетнічних систем. Химера - це форма контакту несумісних етносів різних суперетнічних систем, за якого зникає ї своєрідність. Химера характеризується як загал деетнізованих людей, етнічних маргіналів, що втратили рідні етнічні стереотипи та етнічні традиції. Результатом такої етнічної дисфункції стає психічна дезадаптація 3 відповідними розладами нервової системи людини. На відміну від етносу, химера не може розвиватися, а паразитує деякий час у його тілі. Здебільшого вони складаються під час вторгнення представників одного суперетносу на терени проживання іншого, після чого агресор намагається жити не за рахунок освоєння ландшафту, а за рахунок переможених. Химера як псевдоетнічна спільнота, протиставляє себе всім, відкидаючи традиції й заміняючи їх постійним оновленням «новизни». Тобто в химери немає вітчизни, що робить іï чутливою до негативного світосприймання. Тому химери - поживне середовище для виникнення антисистем, що будуються за принципом обману - стереотип як генерального стереотипу поведінки i найчастіше оселяються у мегаполісах, портових, прикордонних містах. Звичайно, не всі деетнізовані люди входять до антисистем, а виключно ті, кому притаманне негативне світосприймання. Коли під впливом яких-небудь зовнішніх чинників негативне світосприймання починає домінувати, етнос або його частина мутує в антисистему.

\title{
Література
}

1. Гумилев Л. Н. Этногенез и биосфера Земли / Л. Н. Гумилев. - Л. : АйрисПресс, 2007. - 560 с. 2. Лебедева Н. М. Базовые ценности русских на рубеже XX1 века / Н. М. Лебедева // Психологический журнал. - 2000. - Т. 22. - № 3. - С. 75-89. 3. Кон И. С. Социология личности / И. С. Кон. - М. : Политиздат, 1967. - 383 с. 4. Солдатова Г. У. Психология межэтнической напряженности / Г. У. Солдатова. М. : Смысл, 1998. - 386 с. 5. Фрейд 3. Работы о мазохизме / З. Фрейд; [пер. с нем.] / 3. Фрейд. - М. : РИК «Культура», 1992. - 384 с.

УДК 681.515:378

Людмила Цвіркун

\section{ІНФОРМАЦІЙНО-КОМУНІКАЦІЙНІ ТЕХНОЛОГІЇ ЯК ЧИННИК МОТИВАЦІЇ У НАВЧАННІ ГРАФІЧНИХ ДИСЦИПЛІН}

Цвіркун Л. О. Інформаційно-комунікаційні технології як чинник мотивації у навчанні графічних дисциплін.

У статті розглянуто можливості інформаційно-комунікаційних технологій, що сприяють посиленню уваги та інтересу до навчання графічних дисциплін за рахунок наочності і візуалізації. 3'ясовано, що виконання моделюючих завдань, інженернографічних робіт та навчальних проектів за допомогою сучасних графічних програм сприяє посиленню мотивації до графічної підготовки.

Ключові слова: інженер, графічні дисципліни, інформаційно-комунікаційні технології, мотивація, проектно-конструкторська компетентність.

Цвиркун Л. А. Информационно-коммуникационные технологии как фактор мотивации в обучении графических дисциплин.

В статье рассмотрены возможности информационно-коммуникационных технологий, способствующие усилению внимания и интереса к изучению 
графических дисциплин за счет наглядности и визуализации. Выяснено, что выполнение моделирующих заданий, инженерно-графических работ и учебных проектов с помощью современных графических программ способствует усилению мотивации в графической подготовке.

Ключевые слова: инженер, графические дисциплины, информационнокоммуникационные технологии, мотивация, проектно-конструкторская компетентность.

Tsvirkun L. O. Information and communication technology as a motivating factor in learning graphic disciplines.

The possibilities of information and communication technologies that increase the attention and enthusiasm for learning graphic disciplines due to the visibility and visualization, it is found that the performance of the tasks of modeling, engineering and graphic works and educational projects with the help of modern graphics software enhances motivation in graphic preparation.

Key words: engineer, graphic disciplines, information and communication technology, motivation, design and engineering expertise.

У зв'язку з постійним розвитком інформаційних технологій спостерігається інноваційна спрямованість освітнього процесу ВНЗ. Це сприяє активізації науковотехнічної та професійної діяльності майбутніх інженерів, що вимагає оволодіння низкою компетенцій, 3-поміж яких проектно-конструкторська компетентність посідає одне 3 чільних місць. В умовах сьогодення майбутній фахівець повинен не лише правильно читати креслення та схеми, виконувати інженерно-графічні завдання, оперувати просторовими образами, а й уміти застосовувати інформаційні технології та сучасні графічні програми у процесі професійної діяльності.

Відповідно, графічна підготовка повинна проходити із застосуванням новітніх технологій та забезпечувати всебічний розвиток майбутнього інженера. Про це свідчать Проект Закону України «Про діяльність у сфері інформатизації», закони України «Про Національну програму інформатизації», «Про основні засади розвитку інформаційного суспільства в Україні на 2007-2015 роки», у яких зазначено, що 3поміж основних завдань вищої освіти є формування інформаційної, дослідної, проектно-конструкторської компетентності зокрема, насамперед через створення системи освіти, зорієнтованої на використання інноваційних технологій у формуванні компетентного фахівця [4]. Тому для успішної професійної діяльності студенту необхідно усвідомити можливості комплексного поєднання традиційних та інноваційних технологій, що забезпечить підготовку інженерних кадрів, здатних професійно розв'язувати завдання виробничого характеру.

У процесі вивчення графічних дисциплін необхідно зацікавлювати студентів до майбутньої професійної діяльності, навчати використовувати отримані знання у процесі розв'язання завдань професійного спрямування, що сприятиме формуванню широкого наукового світогляду й мотивації до здобуття нових знань. Тому застосування графічних програм спонукатиме майбутніх інженерів не лише до плідної та продуктивної роботи, а й мотивації до навчання, насамперед через уміння працювати в команді, використовуючи комунікативні уміння й самостійний досвід.

Mema cmammi- розглянути можливості інформаційно-комунікаційних технологій, які сприяють формуванню проектно-конструкторської компетентності майбутнього інженера у процесі графічної підготовки. 
У контексті проблеми, що з'ясовується, слід зауважити, що інформаційні технології мають великий потенціал у формуванні творчої особистості, здатної актуалізувати свої здібності та віднаходити шляхи вияву індивідуальної активності. Науковці, які досліджують вплив інформаційно-комунікаційних технологій на процес навчання графічних дисциплін зокрема (Н. Апатова, Р. Горбатюк, Р. Гуревич, Т. Дикова, М. Жалдак, Ю. Жук, В. Козуб, Є. Мартин, Ю. Машбиць, К. Мілян, В. Молочков, В. Монахова, І. Нищак, О. Пузанкова, Т. Рак, Г. Райковська, А. Ренкас, I. Роберт, В. Савенко, Г. Селевко, В. Селезень, Н. Тализіна, М. Юсупова, Т. Чемоданова, Н. Федотова, І. Шишковська, А. Цукар) зазначають, що новітні технології активізують пізнавальну та мотиваційну діяльність, інтерес до опанування новими знаннями і уміннями, процес мислення й уяви, що робить навчальний процес більш технологічним та результативнішим.

Так, В. Молочков уважає, що застосування інформаційних технологій у графічній підготовці майбутніх інженерів урізноманітнює навчальний процес, підвищує його динамізм, що сприяє формування позитивної мотивації до дисциплін графічного циклу [6, c. 54]. Це спонукає студентів до плідної роботи, пожвавлює навчальний процес за рахунок наочності і візуалізації, забезпечує виникнення інтересу до проектно-конструкторської діяльності. Відповідно, успішність формування проектно-конструкторської компетентності залежить від багатьох чинників, серед яких мотивація до навчання графічних дисциплін посідає одне із чільних місць.

Науковці, які досліджують проблеми мотиву та мотивації (Л. Божович, В. Ковальов, Г. Кострюк, А. Леонтьєв, А. Маркова, А. Маслоу, В. Мерлін, С. Рубінштейн, Х. Хекхаузен, П. Якобсон) розглядають мотив багатогранно: інтереси, потреби, емоції (почуття), наміри, спонукання, стимули, що підкреслює його значущість і необхідність у процесі навчання. Так, О. Деджула вважає, що графічну підготовку необхідно розглядати як цілісну педагогічну систему, де основними компонентами $\epsilon$ студент (його потреби, мотиви, інтереси); викладач (його спрямовуюча, координуюча, контролююча діяльність) [2, с. 9]. Тому у процесі вивчення графічних дисциплін у майбутніх інженерів повинна формуватися позитивна мотивація до проектно-конструкторської діяльності. Це спонукатиме виникненню мотивів до аналізу, конкретизації, прогнозування власної діяльності, а також потреб у побудові просторових наочних моделей деталі, виконанні інженернографічних робіт, навчальних проектів, застосовуючи сучасні графічні програми: Компас, AutoCad, CorelDraw тощо.

Ураховуючи індивідуальні здібності, внутрішні стимули та потреби, майбутній інженер будує процес пізнання самостійно. Викладач виконує координувальну функцію, допомагаючи знайти правильні та оригінальні шляхи розв'язування конкретного завдання практичного та теоретичного характеру. Таке спілкування викладача зі студентом гарантує створення сприятливих умов для ефективної графічної підготовки.

3 огляду на вищезазначене можна стверджувати, що формування мотивації до навчання графічних дисциплін $є$ однією 3 актуальних проблем сучасної педагогіки. Науковці, що досліджують проблеми навчальної мотивації (В. Асеєв, Ю. Бабанський, Н. Бібік， В. Бондар， Л. Божович， І. Підласий, М. Скаткін, О. Савченко, Г. Щукіна) вважають, що мотивація впливає на всі психологічні процеси студента- увагу, уяву, сприйняття, пам'ять, мислення. Окрім того, наголошують, що мотивація - це динамічний процес, механізм, який сприяє активізації внутрішніх мотивів та забезпечує їх взаємодію. Так, В. Асеєв розглядає «мотивацію» як процес спонукання до діяльності [1, с. 12]. 
Відповідно, чим вищою є мотивація в навчанні графічних дисциплін, тим більше прагнення студентів до отримання нових знань.

Слід зауважити, що мотивація може змінюватися в процесі діяльності, бо в залежності від навчальної ситуації змінюється активність того чи іншого мотиву. Так, Х. Хекхаузен зауважує, що мотивація $є$ чинником, що впливає на завзятість у здійсненні вибраної дії та досягнення його результату [7, с. 35]. Тому велике значення у процесі графічної підготовки мають можливості інформаційно-комунікаційних технологій, які сприяють формуванню проектно-конструкторської компетентності майбутнього інженера у процесі графічної підготовки:

- наочність (дозволяє сприймати прості геометричні фігури та складні моделі деталей);

- візуалізація (представляти графічну інформацію у вигляді тривимірної комп'ютерної графіки, анімації, презентації тощо);

-моделювання (дозволяє більш розгорнуто та реалістичною зображувати тривимірні наочні моделі деталей). Окрім того, можливості графічних програм полегшують сприйняття та закріплення матеріалу та підвищують ефективність навчального процесу, рис. 1.

Відповідно, у проектно-конструкторській діяльності інженерів відкривається безліч можливостей моделювання тривимірних об'єктів різної складності за допомогою інформаційних технологій та графічних програм. Так, О. Кудрявцев зауважує, що на базі тривимірної моделі деталі можна створити три стандартних асоціативних види, які асоціативно пов'язаний із певною 3D моделлю, у процесі зміни форми або розмірів моделі змінюється зображення на всіх пов'язаних 3 нею асоціативних видах [5, с. 21]. Це забезпечить у процесі виконання завдань на моделювання змогу побачити побудовану деталь 3 усіх сторін, внутрішню будову деталі, виконавши перерізи, розрізи тощо. Усвідомлення процесу побудови сприятиме посиленню мотивації у майбутніх інженерів до навчання графічних дисциплін.

Останнім часом розв'язування багатьох виробничих завдань неможливе без застосування інформаційно-комунікаційних технологій, що вимагає формування у майбутніх фахівців практичних умінь та навичок виконання інженерно-графічних робіт та оформлення технічної документації згідно зі встановленими ГОСТами і стандартами. Так, Т. Дикова вважає, що застосування комп'ютерних програм у процесі графічної підготовки дозволяє формувати такі якості: уміння самостійно мислити; віднаходити різні підходи до розв'язування інженерно-графічних завдань; самостійно засвоювати інформацію; формувати професійні знання, уміння та навички; розвивати здатність орієнтуватися в новій ситуації [3, с. 39].

Практика показує, що майбутні інженери мають бажання виконувати інженернографічні роботи та самостійно розв'язувати проблеми у процесі їх побудови. Студентів мотивує змога звільнитися від рутинних дій; однотипного виконання графічних завдань, які на комп'ютері виконуються точніше і швидше, що дає змогу багаторазово використовувати креслення або його фрагменти. Окрім того, графічні програми прискорюють процес розроблення інженерно-графічних робот та технічної документації до неї.

У контексті окресленої проблеми слід зауважити, що інформаційнокомунікаційні технології мають великий потенціал у процесі виконання навчальних проектів творчого характеру, насамперед через уміння працювати в команді, застосовуючи комунікативні уміння та самостійний досвід. Індивідуальний внесок у спільну творчу діяльність $є$ значущим для всіх учасників проекту, оскільки вони несуть відповідальність за успішність всього проекту. 


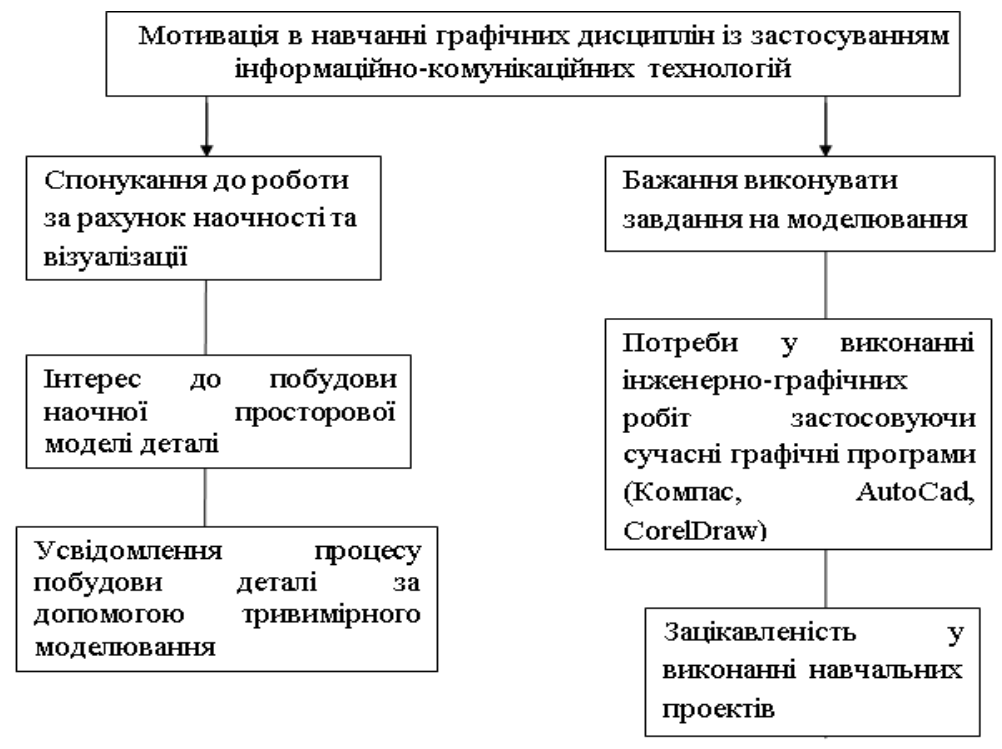

Рис. 1. Мотивація в навчанні графічних дисциплін із застосуванням інформаційно-комунікаційних технологій

Це зоорієнтовує не лише до застосування отриманих знань і набуття нових, а й спонукає майбутніх інженерів до плідної та продуктивної роботи у процесі графічної підготовки.

Під час роботи над такими проектами студенти залучаються до реальної проектно-конструкторської діяльності, що стимулює мотивацію до отримання нових знань і можливість активізувати творчий та інтелектуальний потенціал. Тому виконання навчальних проектів із застосування інноваційних технологій забезпечує оволодіння теоретичними відомостями та практичними уміннями розв'язання навчальної проблеми, що сприяє підвищенню дослідної, проектної і конструкторської діяльності майбутніх інженерів. Це спонукає до вмотивованої діяльності, бо результат роботи можна побачити, осмислити та презентувати.

Відповідно, у процесі графічної підготовки після розроблення наочних просторових моделей, виконання інженерно-графічних робіт доцільно закріпити отримані знання під час виконання навчальних проектів, де потрібні знання не лише традиційних методів та правим побудови графічних зображень, а й можливості, що надають інноваційні технології. Виконання таких завдань за допомогою сучасних графічних програм не лише сприяє посиленню мотивації до навчання графічних дисциплін, а $\epsilon$ ефективним засобом та потужним стимулом формування проектноконструкторської компетентності майбутніх інженерів.

Отже, можливості, що надають інформаційно-комунікаційні технології, дозволять посилити мотивацію до вивчення графічних дисциплін, сконцентрувати увагу майбутніх інженерів на розв'язанні конкретної навчальної проблеми, що сприятиме не лише отриманню необхідного обсягу теоретичних і практичних знань, а й умінню працювати в колективі. Окрім того, посилюють увагу та інтерес до 
графічної підготовки за рахунок наочності та візуалізації, що сприяє формуванню позитивного ставлення до майбутньої проектно-конструкторської діяльності.

\section{Література}

1. Асеев В. Г. Мотивация поведения и формирование личности / В. Г. Асеев. М. : Мысль, 1976. - 158 с. 2. Джеджула О. М. Теорія і методика графічної підготовки студентів інженерних спеціальностей вищих навчальних закладів: автореф. дис. на здобуття наук. ступеня канд. пед. наук: спец. 13.00.04 «Теорія і методика професійної освіти» / О. М. Джеджула. - Тернопіль, 2007. - 44 с. 3. Дикова Т. В. Информационные технологии как способ активизации познавательной деятельности студентов / Т. В. Дикова // Информационно-коммуникационные технологии в подготовке учителя технологии и учителя физики: материалы науч.-практ. конфер., 7-9 апреля 2010 г. : [в 2-х ч. / отв. ред. А. А. Богуславский]. - Коломна : Из-во МГСГИ, 2010. - Ч. ІІ. - С. 38-41. 4. Закон України «Про Національну програму інформатизації» № 74/98-ВР від 04.02.1998p. / Президент України. - Режим доступу : laws/show/74/98-вр. 5. Кудрявцев Е. М. КОМПАС-3 D V7. Найбільш повне руководство / Е. М. Кудрявцев. - М. : ДМК Пресс, 2006. - 664 с. 6. Молочков В. П. Формирование графической культуры будущих учителей на основе использования информационных технологий обучения : дис. ... канд. пед. наук : 13.00.08/ Молочков Владимир Петрович. - Великий Новгород, 2004 - 152 с. 7. Хекхаузен Х. Мотивация и деятельность / Х. Хекхаузен. - М. : Педагогика, 1986. - 408 с. 